\title{
Problem militarnej funkcji toporów późnośredniowiecznych wojowników Wielkiego Stepu
}

The Problem of the Military Function of the Axes of the Late Medieval Warriors of the Great Steppe

\begin{abstract}
Abstrakt: Topory późnośredniowiecznych koczowników Wielkiego Stepu nie doczekały się jak dotąd większej uwagi badaczy. Informacje o nich są skąpe. Nie ma żadnych ikonograficznych wizerunków. Jedynie Jan de Plano Carpini napisał w swoim tekście, że Mongołowie używali toporów do zabijania jeńców. W tekstach mongolskich znajduje
\end{abstract}

się informacja, że były one używane jako narzędzia pomocnicze podczas wypraw wojennych. Istnieje kilka zabytków archeologicznych, które czasami uważane są za topory nomadów. Ich bliższa ocena jest jednak w tym względzie negatywna. Dla późnośredniowiecznych wojowników Wielkiego Stepu topory nie stanowiły ważnej broni.

Słowa kluczowe: wojownicy Wielkiego Stepu, późne średniowiecze, topory, broń

W dotychczasowych studiach nad późnośredniowiecznym uzbrojeniem wojowników Wielkiego Stepu wyraźna jest dysproporcja zainteresowań poszczególnymi jego kategoriami. Jest już stosunkowo wiele opracowań podejmujących problematykę broni miotającej, siecznej, hełmów, osłon tułowi. Toporom nie poświęcono, jak dotąd, specjalnej uwagi. Niewątpliwie wynika to z wyjątkowej skromności informacji o nich, zawartych we wszystkich kategoriach źródłowych.

W źródłach pisanych znaleźć można kilka zaledwie wzmianek o toporach Mongołów. Jan di Piano Carpini, włoski franciszkanin, który z polecenia papieża Innocentego IV, jako jego poset, dotarł latem I246 r. do Centralnej Azji i spotkał się tam z chanem Gujukiem, w swej Historii Mongotów, w akapicie poświęconym uzbrojeniu, które powinni posiadać wojownicy mongolscy, wymienił „siekierę” (w oryginale: securis), dodając następnie: ipowrozy do ciagnięcia machin wojennych (The Texts... 1903: 62). Należy więc uznać, że wspomniana przez Carpiniego „siekiera” była przez Mongołów traktowana nie jako broń, lecz narzędzie będące w zestawie wyposażenie wojownika w trakcie wypraw wojennych. Potwierdza to kontekst, w który wymieniony jest „topór” w Tajnej historii Mongotów, rodzimej, 
mongolskiej kronice z I240 $\mathrm{r}$. Występuje on w zapisie wspominającym, że jeden z dowódców Czyngis-chana rozkazał zaopatrzyć swe oddziały w siekiery, topory, pity i świdry (Tajna historia... 1970: 177). Także Tomasz ze Splitu, autor trzynastowiecznej relacji o mongolskim ataku i podboju Węgier w I24I r., napisał, że Mongołowie, przekraczając Karpaty, mieli ponoć ponad 40 ooo ludzi uzbrojonych $\mathrm{w}$ „,iekiery”. Maszerowali oni przed wojskiem i usuwali wszelkie przeszkody na drodze przemarszu. Król Węgier Béla IV, spodziewając się ataku mongolskiego, nakazał i osobiście nadzorował wykonanie zasieków blokujących przejścia przez przełęcze karpackie na wschodnich granicach królestwa. Mongołowie zasieki te zlikwidowali w ciągu zaledwie trzech dni (Świętosławski 2002: 35-36). Sformalizowanie wymogów niemilitarnego wyposażenia stepowych wojowników w narzędzia i sprzęty przydatne podczas wypraw wojennych spotykane było w tradycjach dawnych ludów Wielkiego Stepu. Według relacji chińskich wojownicy Kitanów, bezpośrednich poprzedników Mongołów na stepach centralnoazjatyckich, musieli mieć oprócz broni także: mtotek, szydto i krzesiwo (Damdinsuren 1990: 89; Świętosławski 2008: 146).

Jan di Piano Carpini w swej relacji o „siekierach/toporach” wspomniał jeszcze dwukrotnie. Opisując mongolskie sposoby atakowania twierdz, napisał m.in., że obrońców, którzy się poddali, dzielą na trzy grupy. Rzemieślników i przeznaczonych do niewoli pozostawiają przy życiu. Pozostałych „zabijają siekierą” (w oryginale: securis). Cztery zdania dalej, szczegółowo opisując organizację masowych egzekucji, podał, że dokonywano ich „obosiecznymi toporami” (w oryginale: $b i$ pennis) (The Texts... 1903: 65). W polskim przekładzie Historii Mongotów (autorstwa Stefana Młodeckiego) słowo bipennis przetłumaczone zostało błędnie jako „obosieczny miecz" (Jan di Piano Carpini 1993: 146). W słownikach łacińskich i literaturze bronioznawczej termin ten jest uznawany za oznaczający topór (być może z dwoma ostrzami) (Głosek 1996: 2I-23). Przypomnieć w tym miejscu także należy, że "obosieczne miecze” w rękach wojowników późnośredniowiecznego Wielkiego Stepu były z pewnością wyjątkową rzadkością. Brak o nich wzmianek w źródłach pisanych. Ich przedstawienia nie występują w ikonografii koczowników. Kilka znalezisk tej kategorii długiej broni siecznej, pochodzących z terenów stepów, to zabytki obcej proweniencji o niejasnych okolicznościach odkrycia (Świętosławski 1996: 35).

Obecność w powyżej wspomnianych fragmentach relacji Jana di Piano Carpiniego terminów „siekiera/topór” (securis/bipennis) nie dowodzi uznawania przez Mongołów toporów za broń, a nawet za faktyczne narzędzia dekapitacji. Być może autor, nie będący naocznym świadkiem karania śmiercią przez nomadów (o tym nie napisał), podał nazwy narzędzi kaźni znane mu z jego europejskiego świata.

Symptomatycznym jest, że nie ma późnośredniowiecznych ikonograficznych wizerunków toporów ani na zabytkach powstałych w świecie koczowników 

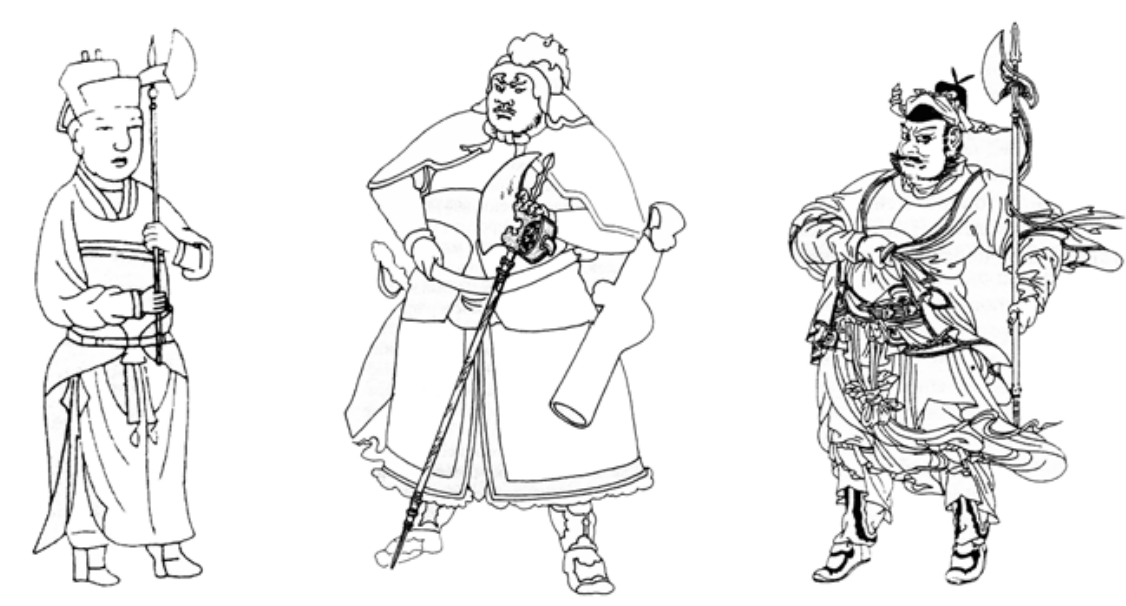

Ryc.1. Sylwetki wojowników z toporami. Chiny, dynastia Yuan.

Za: Bobrov, Khudyakov 2008.

Wielkiego Stepu, ani w dziełach sztuki ich sąsiadów przedstawiających stepowych wojowników. Zarysy militariów zaczepnych, głównie szabli, łuków, noży, widoczne są np. na antropomorficznych połowieckich posągach kamiennych oraz na centralnoazjatyckich rytach naskalnych. Brak jednak wśród nich toporów. Jedynie L.A. Bobrow i Ju.S. Chudjakow w swej monografii późnośredniowiecznego i wczesnonowożytnego uzbrojenia koczowników Centralnej Azji i południowej Syberii zamieścili kilka rycin przedstawiających wojowników z toporami, nie podając jednak argumentów za ich interpretowaniem jako wojowników stepowych (Bobrov, Khudyakov 2008: ryc. I04). Jedynym, co wiąże te wizerunki ze światem nomadów, jest ich pochodzenie z Chin pozostających w latach I279-I368 pod panowaniem mongolskiej dynastii Yuan. Widoczni są na nich mężczyźni w chińskich, a nie mongolskich ubiorach, trzymający topory o wachlarzowatych żeleźcach, umieszczonych na długich drzewcach (ryc. I). Nie ma przesłanki, która mogłaby wspierać hipotezę, że toporów takich mogli używać koczownicy.

W przeciwieństwie do relacji pisanych i przedstawień ikonograficznych nieco więcej jest archeologicznych znalezisk toporów, w przypadku których sformułowano przypuszczenia o związku z późnośredniowiecznymi ludami Wielkiego Stepu.

Południowosyberyjskim toporom, interpretowanym jako militaria koczowników, wspomniani już wyżej L.A. Bobrow i Ju.S. Chudjakow poświęcili cały rozdział. Zdecydowana ich większość pochodzi jednak z czasów nowożytnych i zdaniem autorów są one śladem wpływów ruskich, a może nawet zostały zrobione rękoma rosyjskich kowali (Bobrov, Khudyakov 2008: 326). W trzech tylko przypadkach można ewentualnie rozważać możliwość ich późnośredniowiecznej proweniencji. 


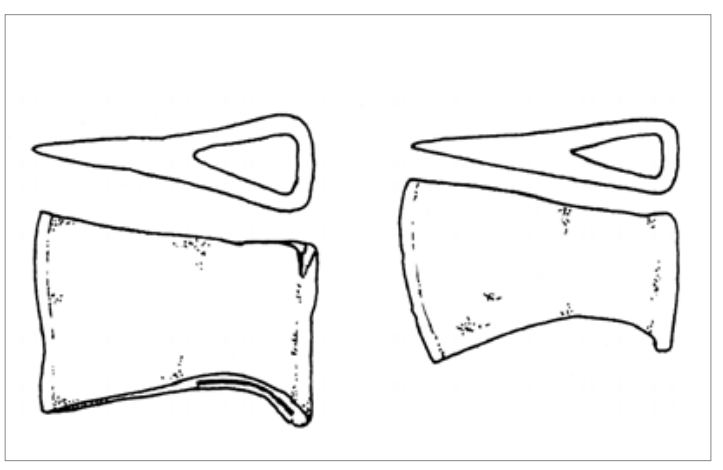

Ryc. 2. Topory. Południowa Syberia (Rosja). Za: Bobrov, Khudyakov 2008.

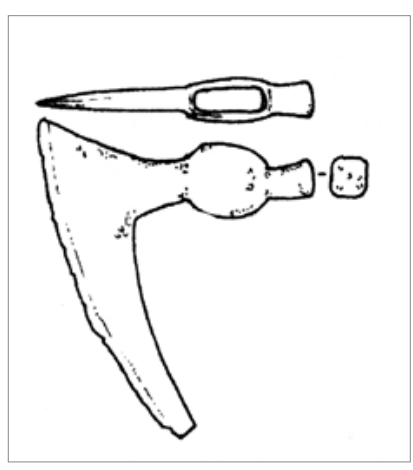

Ryc. 3. Topór z „lasostepowego Ałtaju" (Rosja). Za: Bobrov, Khudyakov 2008.

Dwa, bardzo zbliżone prostotą trapezoidalnej formy, niewielkie okazy bez brody o długości całkowitej $13 \mathrm{~cm}$, z których jeden odkryto na stanowisku Sojan-see w kotlinie Minusińskiej, drugi zaś w Czerdat nad rzeką Czułym w Kraju Krasnojarskim, zdaniem obu autorów reprezentują typ toporów być może używany przez ludność miejscową od późnego średniowiecza po początek XVIII w. (Bobrov, Khudyakov 2008: 322, ryc. I00: I-2) (ryc. 2). L.A. Bobrow i Ju.S. Chudjakow dostrzegli jednak, że zabytki te nie mają analogii w strefie południowosyberyjskiej, lecz na zachodzie Syberii. Topory tego kształtu, stosunkowo liczne (kilkadziesiąt zabytków), znane są z tajgi zachodniosyberyjskiej. Datowano je bardzo szeroko: średniowiecze i czasy nowożytne (Solov'yev 1987: 90-97, ryc. 32-33). Trudno więc zaakceptować wniosek, iż były wyrobami mieszkańców stepu. Południowe obszary Niziny Zachodniosyberyjskiej wielokrotnie wchodziły w skład ułusów potomków Czyngis-chana. Tamtejsza ludność, posługująca się własnym orężem i narzędziami, uczestniczyła zapewne wielokrotnie w działaniach militarnych organizowanych przez Mongołów.

Odosobnioną w Azji formę ma pochodzący z „lasostepowego Ałtaju” czekan długości całkowitej $14 \mathrm{~cm}$, charakteryzujący się bardzo długą brodą $(19 \mathrm{~cm}) \mathrm{z}$ łukowatym ostrzem sięgającym znacznie powyżej linii osady, mającej poszerzone w górę i dół boki, z krótkim młotkiem, kwadratowym w przekroju (ryc. 3). W.W. Gorbunow i A.A. Tiszkin datowali go na XIII-XIV w. (Gorbunov, Tishkin I998: ryc. 4I). L.A. Bobrow i Ju.S. Chudjakow włączyli okaz do puli późnośredniowiecznych militariów koczowników Wielkiego Stepu, choć dostrzegli jego nietypową formę, niespotykaną na terenach azjatyckich. Wskazali, iż czekany takie były popularne w Bułgarii Nadwołżańskiej w późnym średniowieczu i podkreślili, że nie można stwierdzić, jak i kiedy przeniknęły na południe Syberii (Bobrov, Khudyakov 2008: 322, ryc. IO2: 4). Próżno jednak, jak dotąd, szukać na terenach nadwołżańskich 
bliskiej analogii do omawianego zabytku. W trakcie badań archeologicznych niektórych grodzisk Bułgarii Nadwołżańskiej znaleziono czekany z łukowatymi ostrzami, wystającymi powyżej linii osad, mające poszerzone w górę i dół ścianki boczne oraz prostokątne w przekroju młotki, ale nie mają one znacznie wydłużonej brody, co jest cechą charakterystyczną ałtajskiego zabytku. Ostrza ich są wyraźnie krótsze (np. Io cm). Na terenach Bułgarii Nadwołżańskiej są one bardzo rzadkie i datowane na wczesne średniowiecze. A.Ch. Chalikow wskazuje na wieki od $\mathrm{x}$ po XIII w. (Khalikov 1985: I82, tabl. LXI:I), a S.A. Pletnewa uznaje je za pochodzące z X i początków XI w. (Pletneva 1981: ryc. 52: I20).

Czekany najbardziej zbliżone kształtem do zabytku z Ałtaju, mające znacznej długości brody, pochodzą z Europy Środkowej i Południowej: terenów dzisiejszej Polski, Czech, Słowacji, Bułgarii. Są one datowane przez różnych autorów nieco odmiennie. W przypadku okazów polskich sugeruje się przedział od IX po XII w. (Nadolski 1954: tabl. XV: 4; Strzyż 2006: 4I; Kotowicz 20I4: 52; 2018: II5). Zabytki z Czech uznaje się za pochodzące z wieków od viı po początek x (Dostál 1966: 7I), ze Słowacji z IX (Ruttkay 1976: 3II), zaś z Bułgarii z okresu od drugiej połowy IX po połowę XI (Jotov 2004: 92). Znaleziony na Ałtaju zabytek należy więc raczej datować na wczesne niż późne średniowiecze, a chronologiczne oceny W.W. Gorbunowa i A.A. Tiszkina, powtórzone bezrefleksyjnie przez L.A. Bobrowa i Ju.S. Chudjakowa, uznać za bezpodstawne. Choć w literaturze spotkać można sugestie łączenia tej formy z Węgrami (Ruttkay) lub Protobułgarami (Jotov), kwestię proweniencji i ewentualnego jej związku ze światem koczowników wschodnioeuropejskiego stepu uznać należy w chwili obecnej za nierozstrzygniętą, wymagającą dalszych studiów nie tylko gabinetowych, ale przede wszystkim pozyskania większej liczby zabytków. Tym samym nie należy ałtajskiego zabytku interpretować, jak to zrobili L.A. Bobrow i Ju.S. Chudjakow, jako związanego z późnośredniowiecznym uzbrojeniem koczowników Wielkiego Stepu.

Odosobnionymi, jak dotąd, znaleziskami z terenów Azji są dwa topory, które zamiast otworów na drzewce mają trzpienie. Okaz o wachlarzowatym, szerokim ostrzu, częściowo w dolnej części odłamanym, odkryto w warstwie datowanej na XIII w., podczas badań Karakorum, jednego z najważniejszych miast imperium mongolskiego (Kiselev, Merpert 1965: 206, ryc. IIO; Khudyakov 1991: 139, ryc. 76:3; Świętosławski 1996:38, tabl. $\mathrm{XV}: 4)$. Ma on $16,5 \mathrm{~cm}$ długości całkowitej i $15 \mathrm{~cm}$

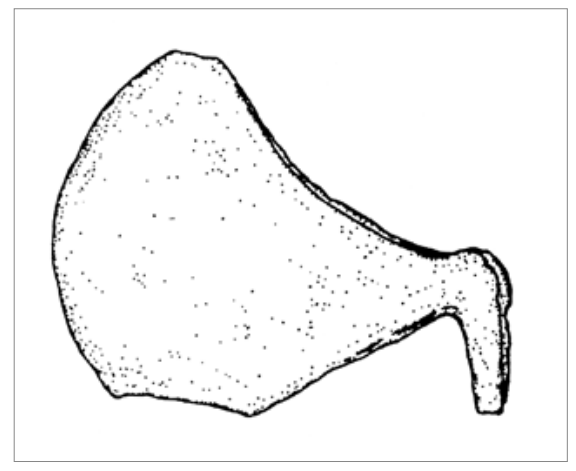

Ryc.4. Topór z Karakorum (Mongolia). Za: Kiselev, Merpert 1965. 


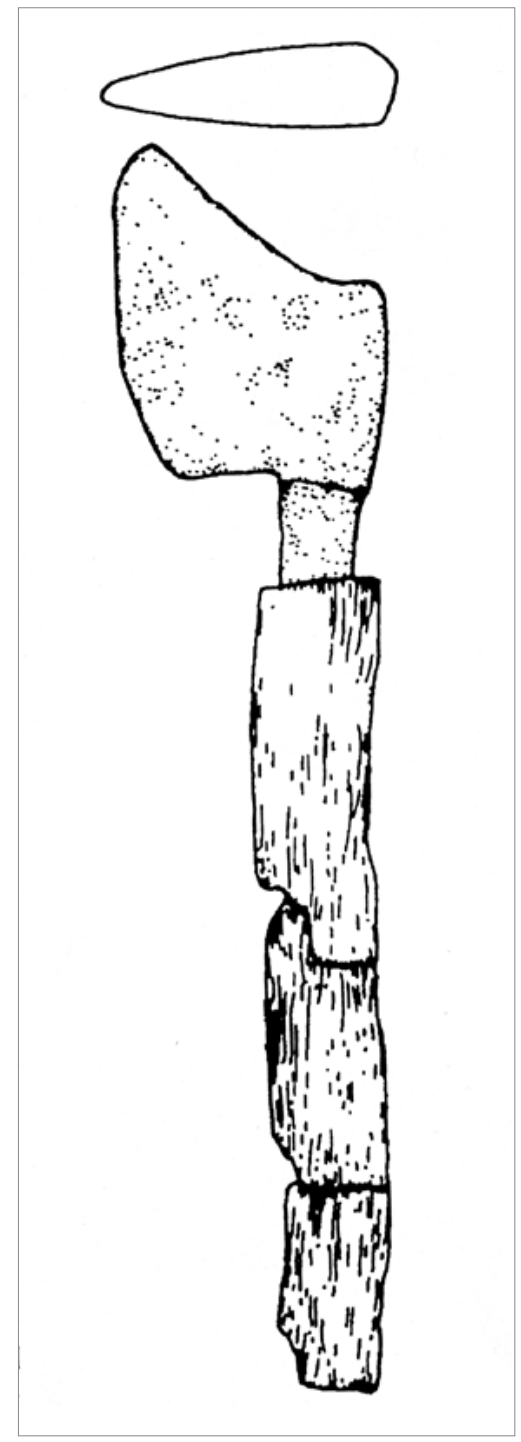

Ryc.5. Topór ze Wschodniego Zabajkala (Rosja).

Za: Aseev i in. 1984. wysokości (ryc. 4). Drugi zabytek ma małe rozmiary. Jego długość całkowita wynosi zaledwie $6 \mathrm{~cm}$, wysokość $8 \mathrm{~cm}$. Zachowało się około trzydziestocentymetrowej długości drewniane stylisko w przekroju okrągłe (ryc. 5). Mimo iż toporek znaleziono na stanowisku Czindant we wschodniej części Zabajkala, w więc już w strefie tajgi (Aseev $\mathrm{i}$ in. 1984: tabl. XLI:3), a nie stepu, przez Ju.S. Chudjakowa uznawany jest wraz z wymienionym wyżej zabytkiem z Karakorum za topory bojowe Mongotów z XIII-XIV w., choć z uwagą, że nigdy formy te nie stały się popularne (Khudyakov I991: 139). Być może w przypadku toporka z Czindant Ju.S. Chudjakow wycofał się z interpretowania go jako należącego do kultury materialnej ludów stepu. W swej, wspomnianej już tu wyżej, najnowszej monografii późnośredniowiecznego i wczesnonowożytnego uzbrojenia koczowników Centralnej Azji i południowej Syberii zabytku tego nie uwzględnił (Bobrov, Khudyakov 2008).

Oba okazy, zarówno egzemplarz z Karakorum, jak i z Czindant, choć mające nieco odmienne kształty, charakteryzują się posiadaniem trzpienia i łukowatym ostrzem. Niewątpliwie są to zabytki, w przypadku których nasza wiedza jest wyjątkowo skromna. Podkreślić należy, iż toporom z trzpieniem nie poświęcono, jak dotąd, wiele uwagi. Nie zostały uwzględnione w podstawowych pracach poświęconych późnośredniowiecznym znaleziskom broni obuchowej z Europy Wschodniej i Środkowej. Brak o nich wzmianki np. w monografiach A.N. Kirpicznikowa czy M. Głoska. Zwrócili na to uwagę P. Kotowicz i A. Michalak w swym artykule poświęconym kilkunastu toporom z trzpieniem, znalezionym na terenach dzisiejszej Polski. Już w tytule tekstu autorzy zaznaczyli swe przekonanie, że okazy te mają charakter militarny. Podkreślając, iż są to 
zabytki XIV-XV w., a więc młodsze od trzynastowiecznych ataków mongolskich na ziemie polskie, sformułowali ostrożny sąd o możliwości ich miejscowego wytworzenia, ale pod wpływem inspiracji mongolskich. Zaznaczyli, że stan naszej wiedzy o tej kategorii zabytków jest nikły (Kotowicz, Michalak 2007: 2I). Niestety, mimo upływu kilkunastu lat od ukazania się artykułu P. Kotowicza i A. Michalaka nie pojawiły się nowe dane, które mogłyby rzucić nieco więcej światła na kwestię ewentualnych związków późnośredniowiecznych toporów z trzpieniami i łukowatymi ostrzami ze światem koczowników. Spośród wszystkich, dotąd znanych, jedynie zabytek z Karakorum ma bezsporne pochodzenie z terenu Wielkiego Stepu. Jednakże i on nie musi być wyrobem mongolskim. Wachlarzowata forma żeleźca w pewnej mierze nawiązuje do kształtów toporów widocznych w ikonografii chińskiej. Być może, pamiętając, iż w Karakorum dominowali rzemieślnicy chińscy, to właśnie w tym kręgu cywilizacyjnym należy poszukiwać tropów proweniencyjnych.

W 1996 r. odkryto w Olen'-Kolodez' koło Woroneża nad Donem (Rosja) grób mężczyzny bogato wyposażony w broń, elementy oporządzenia jeździeckiego, pozłacane części pasa, pozłacaną czarkę i szklany amulet. Był tam też żelazny topór ozdobiony motywem dwurogiego zwierzęcia (ryc. 6). Autor odkrycia datował pochówek na koniec XIII i początek XIV w. Wszystkie zabytki, także topór, uznał za miejscowe wyroby rzemieślników Złotej Ordy (Yefimov 1999; 2000; Altyn urda... 2000: 68, 218). Analizując obrządek pogrzebowy i oceniając odkryte zabytki, uznał, chyba słusznie, że pochowany mężczyzna należał do elity koczowników złotordyńskich.

Topór ma I4,2 cm długości i 9,5 cm wysokości. Z terenów Wielkiego Stepu nie znamy podobnych egzemplarzy. Najbliższe analogie znaleziono najliczniej na obszarach Europy Środkowej (Nadolski 1954: 45; Świętosławski 2014; Kotowicz 20I4: 193; 20I8: 62-64), ale też na Rusi (Kirpichnikov I966: 37), w południowo-wschodnim rejonie nadbałtyckim (Kulakov 1990: 32) i w południowej Skandynawii (Paulsen 1939: 30).

Wyjątkowo efektowną i charakterystyczną cechą zabytku jest bogata, dwustronna inkrustacja, a szczególnie umieszczone na obu stronach żeleźca przedstawienia zwierzęcia o długich, wąskich rogach - tura. Znanych jest kilka bardzo bliskich analogi tego wizerunku, powtarzających nie tylko zarys sylwetki zwierzęcia, ale i szczegóły drugorzędne, np. układ pyska, nóg, ogona, kształt rogów itp. Przedstawienia te zdobią głównie topory, ale też jelce mieczy, a nawet kabłąk strzemienia. Od dwóch wieków trwają studia nad tym motywem ornamentacyjnym i zabytkami, na których go umieszczono. Literatura poświęcona temu tematowi jest bardzo bogata (najnowsze zebranie: Świętosławski 2014; Kotowicz 2018: 62-64). Wśród hipotez dotyczących proweniencji wizerunku i typu toporów, reprezentowanych m.in. przez zabytek z Olen'-Kolodez', dominują sugestie wskazujące na 


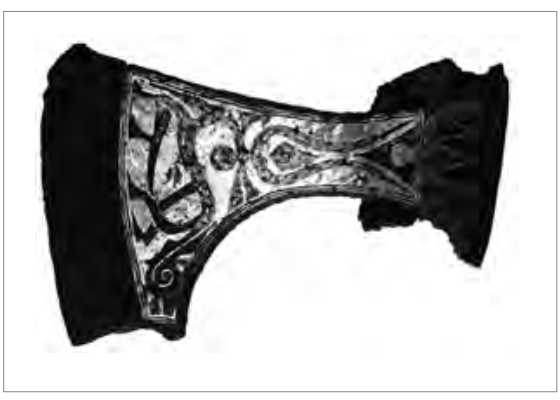

Ryc. 6. Topór z Olen'-Kolodez' koło Woroneża nad Donem (Rosja). Za: Yefimov 1999.

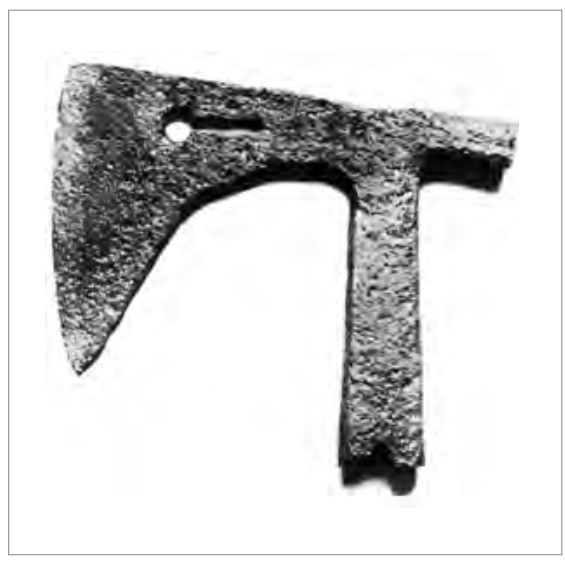

Ryc.7. Topór „znaleziony na Legnickim Polu” (Polska). Za: Jasiński 1988.

Europę Środkową lub tereny nad południowo-wschodnimi wybrzeżami Bałtyku. Jak dotąd, poza odkrywcą topora znad Donu, nikt nie sugerował proweniencyjnych związków z koczownikami i Wielkim Stepem. Zabytek ten jest najprawdopodobniej przykładem, bardzo przecież częstego, zjawiska wędrówki przedmiotów w miejsca odległe od rejonów, w których powstały. Topór z Olen'Kolodez', choć z pewnością u schyłku użytkowania należał do późnośredniowiecznego, stepowego wojownika, nie może być uznanym za przykład stepowego oręża. Jest elementem obcym w kulturze materialnej późnośredniowiecznych koczowników Wielkiego Stepu.

W popularnonaukowym opisie najazdów ludów stepu na ziemie polskie w XIII w., pióra T. Jasińskiego, zamieszczona jest fotografia czekana, opisanego jako topór mongolski zXIII $w$., znaleziony na Legnickim Polu (Jasiński 1988: 55) (ryc. 7). Autor nie przedstawił jakiejkolwiek argumentacji takiego sądu. $Z$ wiązaniem zabytku z trzynastowiecznym najazdem mongolskim nie zgodził się M. Głosek, który datował go na XV w. Uznał za jedyny okaz reprezentujący w jego systematyce toporów późnośredniowiecznych z ziem polskich podtyp Ih, różniący się od podtypu Ig jedynie dłuższą osadą. Nawiązanie do podtypu Ig jest istotne, bowiem jest on stosunkowo licznie reprezentowaną formą czekanów datowanych na ziemiach dzisiejszej Polski na XV, może schyłek XIV w., na terenach Węgier na XIV-XVII w., zaś na Litwie na XIV-XVI w. (Głosek 1996: 30-32). Ważną cechą czekana jest obecność w żeleźcu otworu do wyciągania gwoździ, typowego dla zachodnio- i środkowoeuropejskich ciesielskich toporów od późnego średniowiecza po współczesność. Niewiele wiemy o pochodzeniu zabytku. Nie ma o nim wzmianki w publikacjach badań archeologicznych przeprowadzonych na Legnickim Polu (Siedlak 1961; Wolski 2008). Miejsce jego przechowywania jest nieznane (Głosek 1996: 82). Nie ma podstaw do wiązania go z kulturą materialną ludów stepu. 
Liczba przedstawionych toporów i czekanów, które w dotychczasowej literaturze były bezpośrednio wiązane z wojownikami Wielkiego Stepu, jest bardzo skromna. We wszystkich przypadkach domniemanie, iż mogły być one dziełem stepowych wytwórców jest najprawdopodobniej błędne. Nie oznacza to oczywiście, że późnośredniowieczni koczownicy Wielkiego Stepu nie znali i nie używali toporów. Topór to wszak nie tylko broń, ale również, a może nawet częściej, uniwersalne narzędzie, jedno z najstarszych, powszechnie wykonywanych i użytkowanych przez człowieka. Także starożytni i wczesnośredniowieczni koczownicy Wielkiego Stepu wykonywali i posługiwali się toporami, czego dowodzą znaleziska archeologiczne. Nie można wątpić, iż również późnośredniowieczni koczownicy topory znali i wykorzystywali. Znikomość o nich informacji, zawartych we wszystkich kategoriach źródeł, a właściwie prawie zupełny ich brak, w pewnej mierze jest wynikiem stanu badań, ale zapewne również odzwierciedleniem funkcji toporów w świecie ówczesnych nomadów. Wzmianki w źródłach pisanych wyraźnie wskazują, że topór dla późnośredniowiecznego stepowego wojownika nie był orężem, a narzędziem zabieranym na wyprawy militarne jako element zestawu przydatnego w działaniach niezwiązanych bezpośrednio z walką, może też, jeżeli wzmianka Jana di Piano Carpiniego odpowiada prawdzie, narzędziem kaźni.

Działania wojenne, zainicjowane w XII w. przez Czyngis-chana i realizowane do końca średniowiecza przez jego następców, doprowadziły do uzależnienia od władzy mongolskiej ludności rozległych terenów Europy Wschodniej i większej części Azji. Spośród osiadłych mieszkańców tych obszarów liczni - siłą lub z własnej woli - dołączyli do wojsk koczowników i uczestniczyli w działaniach wojennych. Wielu z nich z pewnością używało własnych toporów. Niektóre mogły trafić od nich w ręce nomadów, jednak nie powinny być opisywane, jak to niekiedy bywa, jako „broń koczowników”.

\section{Bibliografia}

Altyn urda khezinelere. Sokrovishch a Zolotoy Ordy. The Treasures of the Golden Horde (2000), Gosudarstvennyy Ermitazh, Sankt-Peterburg (Алтьн yрда хэзинэлэре. Сокровища Золотой Ордь.. The Treasures of the Golden Horde (2000), Государственный Эрмитаж, Санкт-Петербург).

Aseev I.V., Kirilov I.I., Kovychev Ye.V. (1984), Kochevniki Zabaykal'ya v epokhu Srednevekovya (po materyalam pogrebeniy), Izdatelstvo Nauka, Novosibirsk (Асеев И.В., Кирилов И.И., Ковычев Е.В. (1984), Кочевники Забайкалья в эпоху Средневековя (по матерялам погребений), ИзАателство Наука, Новосибирск).

Bobrov L.A., Khudyakov Yu.S. (2008), Vooruzheniye i taktika kochevnikov Tsentral'noy Azii i Yuzhnoy Sibiri v epokbu pozdnego srednevekov'ya i rannego novogo vremeni (XV-pervaya polovina XVIII v.), Slaviya, Sankt-Peterburg (Бобров $\Lambda$.A., ХуАяков Ю.С. (2008), Вооружение и тактика кочевников Центральной Азии 
и Южной Сибири в эпоху позднего средневековья и раннего нового времени (XV-nервая половина XVIII в.), САавия, Санкт-Петербург).

Damdinsuren A. (1990), Mongolyn zevsgijn tovč tuuch, Ulsyn Khevleliin Gazar, Ulaanbaatar.

Dostál B. (1966), Slovanská pohřebištěze středni doby hradištni na Moravě, Academia, Praha.

Głosek M.(1996), Późnośredniowieczna broń obuchowa w zbiorach polskich, Instytut Archeologii i Etnologii PAN, Warszawa-Łódź.

Gorbunov V.V., Tishkin A.A.(1998), Vooruzhenniye naseleniya lesostepnogo Altaya v mongolskoye vremya (XIII-XIV vv.), [w:] A.N. Kirpichnikov (red.), Voyennaya arkheologiya. Oruzhiye i voyennoye delo vistoricheskoy i sotsiapinoy perspektive, Sankt-Peterburg, s. 262-266 (Горбунов В.В., Тишкин А.А. (1998), Вооруженние населения лесостепного Алтал в монголское время (ХIII-XIV вв.), [w:] А.Н. Кирпичников (red.), Военная археология. Оружие и военное дело в исторической и сочиапьной перспективе, Санкт-Петербург, s. 262-266).

Jan di Piano Carpini (1993), Historia Mongotów, [w:] J. Strzelczyk (red.), Spotkanie dwóch światów. Stolica Apostolska a świat mongolski w potowie XIII wieku. Relacje powstate w zwiąku z misją Jana di Piano Carpiniego do Mongotów, Wydawnictwo Abos, Poznań.

Jasiński T. (1988), Przerwany hejnat, Krajowa Agencja Wydawnicza, Warszawa.

Jotov V. (2004), Vaorazhenieto i snaryazhenieto ot balgarskoto srednovekovie (VII-XI vek), Knigoisdatelstvo zogRAF, Izdatelstvo Abagar, Varna (Йотов В. (2004), Въорбжението и снаряжението от българското средновековие (УІІ-ХІ век), Книгоисаателство ЗогрАФ, ИзАателство Абагар, Варна).

Khalikov A.Kh. (1985), Kul'tura Bilyara. Bulgarskiye orudiya truda i oruzhiye X-XIII vv., Izdatelstvo Nauka, Moskva (Халиков A.X.(1985), Культура Биляра. Булгарские орудия труда и оружие Х-ХІІІ вв., ИзАателство Наука, Москва).

Khudyakov Yu.S. (199I), Vooruzheniye tsentrap’noaziatskikh kochevnikov v epokhu rannego i razvitogo srednevekov'ya, Izdatelstvo Nauka, Novosibirsk (ХуАяков Ю.С. (199г), Вооружение центрапьноазиатских кочевников в эпоху раннего и развитого средневековья, Издателство Наука, Новосибирск).

Kirpichnikov A.N. (1966), Drevnerusskoye oruzhiye. Vyp. 2. Kop’ya, sulitsy, boyevyye topory, bulavy, kisteni IX-XIII vv., „Arkheologiya SSSR. Svod arkheologicheskikh istochnikov", EI-36, Leningrad (Кирпичников А.Н. (1966), Аревнерусское оружие. Bып. 2. Копья, сулищьь, боевые топоры, булавы, кистени ІХ-ХІІІ вв., „Археология сСср. Свод археологических источников”, Е I-36, АенинграА).

Kiselev S.V., Merpert N.Ya. (1965), Zheleznyye i chugunnyye izdeliya iz Kara-Koruma, [w:] Drevnemongol'skiye goroda, Izdatelstvo Nauka, Moskva, s. I88-215 (Киселев С.В., Мерперт Н.Я. (1965), Железные и чугунные изделия из Кара-Корума, [w:], Аревнемонгольские города, Издателство Наука, Москва, s. I88-215).

Kotowicz P.N.(2014), Topory wczesnośredniowieczne z ziem polskich. Katalog źródet, Mitel, Rzeszów.

Kotowicz P.N. (2018), Early Medieval Axes from the Territory of Poland, Polska Akademia Umiejętności, Kraków.

Kotowicz P., Michalak A. (2007), Late Medieval Battle-Axes with Tangs from the Polish Lands. A Component of Tatar or Local Weaponry?, „Fasciculi Archaeologiae Historicae", 20, s. 9-2I. 
Kulakov V.I. (1990), Drevosti prussov VI-XIII vv., Moskva (Arkheologiya SSSR. Svod arkheologicheskikh istochnikov, GI-9) (Кулаков В.И.(1990), Аревости пруссов VI-ХІІІ вв., Москва (Археология СсСР. Свод археологических источников, GI-9)).

Nadolski A. (1954), Studia nad uzbrojeniem polskim w X, XI i XII wieku, Zakład im. Ossolińskich we Wrocławiu, Łódź-Wrocław.

Paulsen P. (1939), Axt und Kreuz bei den Nordgermanen, Ahnenerbe-Stiftung-Verlag, Berlin.

Pletneva S.A. (1981), Ranniye bolgary na Volge, [w:] S.A. Pletneva (red.), Stepi Yevrazii v epokhu srednevekovya, Arkheologiya SSSR, Moskva, s. 77-79 (Пиетнева C.A. (198I), Ранние болгары на Волге, [w:] С.А. Пцетнева (red.), Степи Евразии в эпоху средневековя, Археология СсСР, Москва, s. 77-79).

Ruttkay A. (1976), Waffen und Reiterausrüstung des. o bis zur ernsten Hälfte des I4. Jahrbunderts in der Slowakei, (II), „Slovenská Archeológia”, 24.2, s. 245-395.

Siedlak A. (196I), Badania archeologiczne w 720 rocznice bitwy pod Legnica, „Z otchłani wieków", 3, s. 203-209.

Solov'yev A.I. (1987), Voyennoye delo korennogo naseleniya Zapadnoy Sibiri, Izdatelstvo Nauka, Novosibirsk (Соловьев А.И.(1987), Военное дело коренного населения Западной Сибири, ИзАателство Наука, Новосибирск).

Strzyż P. (2006), Uzbrojenie we wczesnośredniowiecznej Matopolsce, „Acta Archaeologica Lodziensia", 52, s. 7-272.

Świętosławski W.(1996), Uzbrojenie koczowników Wielkiego Stepu w czasach ekspansji Mongotów (XII-XIV w.), „Acta Archaeologica Lodziensia”, 40, s.7-II4.

Swiętosławski W. (2002), The Organization of the Mongols' War Expeditions in the Twelfth and Thirteenth Centuries, „Fasciculi Archaeologiae Historicae”, 25, s. 33-38.

Świętosławski W. (2008), Wyposażenie późnośredniowiecznych wojowników Wielkiego Stepu, „Acta Archaeologica Lodziensia”, 54 (= W. Świętosławski (red.), Nie tylko broń. Niemilitarne wyposażenie wojowników w starożytności i średniowieczu), s. I45-I59.

Świętosławski W.(2014), Topór z wizerunkiem tura z grobu w Olen'-Kolodez' nad Donem - tup ze środkowej Europy, „Gdańskie Studia Archeologiczne”, 4, s. 33-43.

Tajna historia Mongotów (1970), S. Kałużyński (tłum.), Państwowy Instytut Wydawniczy, Warszawa.

The Texts and Versions of John de Plano Carpini and William de Rubruquis as Printed for the First Time by Hakluyt in 1598 Together with Some Shorter Pieces (1903), wyd. C. R. Beazley, London.

Wolski K. (2008), Polskie pola bitew w świetle archeologii, Wydawnictwo i Agencja Informacyjna Waw Grzegorz Wawoczny, Racibórz.

Yefimov K.Yu. (1999), Zolotoordynskiye pogrebeniya iz mogil'nika „Olen'-Kolodez”, „Donskaya arkheologiya”, 3-4, s. 93-Іо7 (Ефимов К.Ю. (1999), Золотоордьнские погребения из могильника „Olen'-Kolodez”, „Аонская археология”, 3-4, s. 93-107).

Yefimov K.Yu. (2000), Zolotoordynskiye pogrebeniya iz mogil'nika „Olen'-Kolodez”, "Rossiyskaya arkheologiya”, I, s. 167-182 (Ефимов К.Ю.(2000), Золотоордьнские погребения из могильника „Olen'-Kolodez”, ,Российская археология”, I, s. $167-182)$. 


\section{Summary}

The axes of the late medieval nomads of the Great Steppe have not received much attention so far. Information about them is sparse. There are no iconographic images. Only John de Plano Carpini wrote in his text that the Mongols used axes to kill prisoners. There is information in Mongolian texts that they were used as auxiliary tools during military expeditions. There are several archaeological relics that are sometimes considered nomad axes. However, their closer assessment is negative in this respect. For the late medieval warriors of the Great Steppe, axes were not an important weapon.

Keywords: warriors of the Great Steppe, late medieval, axes, weapon

Witold Świętosławski

Uniwersytet Gdański

Instytut Archeologii i Etnologii

e-mail: witold.swietoslawski@ug.edu.pl

() by the author, licensee University of Lodz - Lodz University Press, Łódź, Poland. This article is an open access article distributed under the terms and conditions of the Creative Commons Attribution license CC-BY-NC-ND 4.0 (https://creativecommons.org/licenses/by-nc-nd/4.0/) 